\title{
Monitoring the outbreak of equine glanders in Alagoas, Brazil: Clinical, immunological, molecular, and anatomopathological findings
}

\author{
Larissa Otaviano da $\operatorname{Rocha}^{1}$ (D) Luiz André Rodrigues de Lima ${ }^{2}$ (i) \\ Rosângela Maria Santos de Albuquerque ${ }^{(\mathbb{D})}$ Sônia Luisa Silva Lages $^{3}$ (D) \\ Annelise Castanha Barreto Tenório Nunes ${ }^{1}(\mathbb{D})$ Roberto Soares de Castro $^{4}(\mathbb{D}$ \\ Rinaldo Aparecido Mota $^{4}$ (i) Karla Patrícia Chaves da Silva ${ }^{*}$ (i) Marcus Vinícius Dias Falcão ${ }^{4}$ (i)
}

${ }^{1}$ Departamento de Medicina Veterinária, Centro de Ciëncias Agrárias, Universidade Federal de Alagoas (UFAL), 57072-900, Maceió, AL, Brasil. E-mail: karla@vicosa.ufal.br . "Corresponding author.

${ }^{2}$ Agência de Defesa e Inspeção Agropecuária de Alagoas (ADEAL), Maceió, AL, Brasil.

${ }^{3}$ Ministério da Agricultura, Pecuária e Abastecimento (MAPA), Maceió, AL, Brasil.

${ }^{4}$ Departamento de Medicina Veterinária, Universidade Federal Rural de Pernambuco (UFRPE), Recife, PE, Brasil.

ABSTRACT: Glanders is an infectious and often lethal zoonotic disease of equines caused by the bacterium, Burkholderia mallei. This condition is characterized by respiratory, lymphatic, and cutaneous lesions. In this study, we monitored the development of clinical symptoms in animals naturally infected with B. mallei across different equine breeds and also isolated and characterized the disease-causing bacteria. We studied two official glanders outbreaks in the state of Alagoas, Brazil. During the outbreaks, we performed clinical and immunological follow-up of the animals, as well as euthanasia and anatomopathological examination. We also collected diagnostic materials for isolative, phenotypic, molecular, and biological testing. We did not observe any clinical patterns of glanders among animals infected with the same strain of B. mallei. Based on our results, we suggest that early diagnosis of infection should be made through highly sensitive and specific immunoassays. In asymptomatic but positive test cases, we confirmed the importance of conducting pathological, microbiological, and molecular examinations.

Key words: Burkholderia mallei, diagnosis, Equidae, control, pathology.

Monitoramento de surtos de mormo nos equídeos em Alagoas, Brasil: achados clínicos, imunológicos, moleculares e anatomopatológico

RESUMO: O mormo é uma enfermidade infectocontagiosa e frequentemente letal, aguda ou crônica, caracterizada por lesões respiratórias, linfáticas e cutâneas em equideos, porém de caráter zoonótico. Objetivou-se acompanhar o desenvolvimento dos sinais clínicos e de lesões em animais infectados naturalmente por B. mallei em diferentes propriedades de criação de equídeos, e isolar e caracterizar a bactéria causadora da doença. Foram estudados dois focos oficiais para o mormo no estado de Alagoas. Realizou-se o acompanhamento clinico e imunológico dos animais nos focos, eutanásia e exame anatomopatológico dos animais, além de colheita de material para diagnóstico através de técnicas de isolamento, fenotípicas, moleculares e prova biológica. Neste estudo não se observou um padrão clínico para o diagnóstico do mormo em animais infectados com a mesma cepa de B. mallei. O diagnóstico precoce da infecção deve ser realizado por meio de testes imunológicos de elevada sensibilidade e especificidade. Nos casos assintomáticos e positivos nos testes oficiais é importante a realização do exame anatomopatológico, microbiológico e molecular.

Palavras-chave: Burkholderia mallei, epidemiologia, diagnóstico, equideos, controle, pathologia.

\section{INTRODUCTION}

Glanders is an infectious zoonotic disease affecting equines, which is often lethal. It is caused by the bacterium, Burkholderia mallei, and is characterized by respiratory, lymphatic, and cutaneous lesions in solipeds and presents as an acute or chronic infection (LEOPOLDINO et al.,
2009; MOTA \& RIBEIRO, 2016). Owing to the high mortality rate in equines and an increased number of outbreaks in recent years, glanders can be considered an endemic and reemerging disease (KHAN et al., 2013). The common mode of infection is through contaminated hay, troughs, and drinking fountains by the oral and nasal secretions of sick animals. Sporadically, dissemination occurs through the direct 
contact with open wounds or through the use of shared tools (MOTA, 2006; RADOSTITS et al., 2010).

Most outbreaks of glanders in the northeastern region of Brazil occur on farms in the sugarcane-producing regions that use distinct species of equines: horses (Equus caballus), mules (Equus asinus $\mathrm{x}$ Equus cabalus) and donkeys (Equus asinus) as draft and saddle animals. Often, these animals present with chronic glanders and have already undergone previous antimicrobial treatment. They show symptoms of late-stage glanders, including bronchopneumonia with progression to death due to anoxia (MOTA et al., 2000; LEOPOLDINO et al., 2009). In southern and southeastern Brazil, glanders is usually observed in animals used in equestrian sports, exhibitions, and recreation. In these cases, the transmission is directly related to the acquisition and introduction of infected animals without any suggestive symptoms in natural herds. Sometimes the equine presence in events could be a contamination sources

In general, the nutritional management, health conditions, and movement of infected animals are important factors in the spread and transmission of glanders. Current containment measures include interdiction of animal movement from the outbreak location, euthanization of infected animals, and property sanitization (MOTA et al., 2000; LEOPOLDINO et al., 2009). The objective of this study were to follow-up two farms with glanders outbreaks and to report the immunological aspects, evolution of clinical signs, and pathological characteristics in equines naturally infected by $B$. mallei.

\section{MATERIALS AND METHODS}

After studying official serological tests administered by the Ministry of Agriculture, Livestock, and Foods Supply (MAPA), we identified two glanders outbreaks, which were monitored in 2017 and 2018. The first outbreak was in the municipality of São Luiz do Quitunde, east of Alagoas, Brazil. The second was located in the municipality of Satuba, in the metropolitan region of Maceió, Alagoas State, Brazil.

The animals in both locations were identified as positive using the official equine transit test [complement-fixation test (CFT) and the confirmatory test, western blotting (WB), for glanders in Brazil], performed in an official MAPA laboratory (MAPA, 2018). Subsequently, samples were subjected to ELISA (Biovetech ${ }^{\circledR}$, I-ELISA) to check the immune response of infected and uninfected animals.

The first focus (FA) evaluated 11 animals: eight horses (Equus caballus), two donkeys (Equus asinus), and one mule (equus asinus $x$ Equus caballus). These animals were used for traction and transportation on a sugarcane plantation. Three animals presented symptoms of clinical glanders and were isolated to monitor clinical progress. For four months, weekly follow-up visits were made to obtain clinical data and collect biological material.

The second focus (FB) evaluated five equines, all positive in serological tests and showing clinical symptoms. These animals were used for recreation and sports. Two follow-up visits were conducted.

Following the procedures and methods approved by the Federal Council of Veterinary Medicine, the Official Veterinarian Service of Alagoas State euthanized animals in their original establishments. Necropsies were conducted on three animals from FA and one from FB (CFMV, 2013; MAPA, 2018).

Nasal swabs were collected for bacterial isolation. During necropsy, veterinarians collected samples of abscesses, lesions, and organ fragments (lymph nodes, lungs, spleens, and livers) with lesions.

Swabs, organs, and abscess materials were seeded in Petri dishes containing a blood-agar base enriched with 5\% defibrinated sheep blood. The plates were incubated for $72 \mathrm{~h}$ at a constant temperature of $37{ }^{\circ} \mathrm{C}$ under aerobic conditions. Samples were taken after 24,48 , and $72 \mathrm{~h}$ of incubation.

After bacterial isolation, $B$. mallei colonies were tested for catalase, oxidase, acetoin, citrate, urease, lysine decarboxylase, indole, and $\mathrm{H}_{2} \mathrm{~S}$ production, as well as glucose fermentation, motility, pigment production, gas from glucose, and carbohydrate fermentation (glucose, maltose, galactose, lactose, fructose, mannose, sucrose, and mannitol) following procedures outlined by AL-ANI et al. (1998). Methyl red-VM and Proskauer Voges tests were used for these determinations.

After phenotypic identification, the $B$. mallei isolates were confirmed using PCR. DNA was extracted using the PROMEGA ${ }^{\circledR}$ DNA extraction and purification kit for gram-negative bacteria, following the manufacturer's recommendations. We performed conventional PCR for genus and species using the SimpliAmp Applied Biosystem thermal cycler. For identification of the species of the Burkholderia genus, we used the primers BURK fD1(5'-CCGAA TTCGTCGACAACAGAGTTTGATCCTGGCTC AG-3') and BURK rD1(5'-CCCGGGATCCAAGC TTAAGGAGGTGATCCAGCC-3') as described by Segonds et al. (1999).

Conventional PCR for species was performed to search for differences in the sequences 
of B. mallei strain ATCC 23344T and B. pseudomallei strain K96243 fliP. The primers used were Bma-IS407fliPf(5'-TCAGGTTTGTATGTCGCTCGG-3')andBmaIS407-fliPr(5'-CTAGGTGAAGCTCTGCGCGAG-3'), in a final reaction volume of $12.5 \mu \mathrm{L}$ using Go-Taq green PROMEGA ${ }^{\circledR}$, and 10 pmol primers as directed by Scholtz et al. (2006). The positive control for both reactions was the standard strain $B$. mallei ATCC15310.

After phenotypic and molecular identification, $0.1 \mathrm{~mL}$ of saline containing inoculum from $B$. mallei isolates was injected intraperitoneally into guinea pigs (Cavia porcellus). Guinea pigs were observed for seven days to evaluate the development of purulent orchitis, a clinical sign of $B$. mallei infection in guinea pigs as reported by Mota et al. (2008). Samples from smears and purulent exudates were collected upon necropsy and subjected to microbiological testing for re-isolation of $B$. mallei strains.

\section{RESULTS AND DISCUSSION}

In FA, three of eleven animals (two horses and one donkey) were initially determined to be clinically positive based on CFT and WB. After diagnosis confirmation, these animals were isolated for symptom evolution observation for six months. Initially, the animals presented a slight bilateral nasal secretion from which the first $B$. malle $i$ sample, UFAL1 , was isolated and identified. During the observation period, the seropositive animals recovered and no presented clinical signs.

After six months, all animals were euthanized and samples were collected. After necropsy, the lungs, liver, spleen, and lymph nodes from these animals were also sent for analysis.

During sanitation of the property, a fourth equine without clinical signs was found to be infected based on an I-ELISA test. Symptoms began to present as expectoration of mucopurulent secretion and posterior limb edema. The animal died seven days after the onset of clinical symptoms. Even with symptoms suggestive of glanders and seropositive in I-ELISA, this animal remained negative in CFT.

At the fourth month of follow-up, a fifth animal exhibited infection as determined based on CFT, WB, and I-ELISA findings; however, it did not develop clinical signs suggestive of glanders throughout the study. It was observed that even with positivity no presented clinical signs during the weeks or months.

In FB, symptomatic animals presented with limb edema, ulcerated lesions, disseminated lymphangitis, sanguinolent bilateral nasal discharge, and severe dyspnea (Figure 1A). They also presented with apathy, lymph vessel nodules, and bilateral mucopurulent nasal discharge (Figure 1B and 1C). The animals were euthanized and samples were collected to isolate and identify the second $B$. mallei sample, UFAL-2 (Figure 1F).

Upon necropsy of animals without clinical signs from FA, characteristic lesions of chronic glanders were observed. Of the three seropositive animals, one had pyogranuloma lesions in the lungs, heads, and lymph nodes of the neck. In FB, necropsy revealed pyogranulomatous lesions in the lungs (Figure 1D and $1 \mathrm{E})$, submandibular lymph nodes, and liver.

According to Gonzalez-Medina et al. (2015) and SAID et al. (2016), glanders tends to be more acute and have higher mortality rates in donkeys and mules. Horses, on the other hand, usually present a chronic form. Chronic infections develop over weeks to months, and the affected animals can go long periods without clinical signs suggesting glanders.

The clinical signs and necropsy findings observed in this study corroborate those described by Mota et al. (2006) and GONZALEZ-MEDINA et al. (2015), who reported symptoms characteristic of glanders in equines with predominant lesions in the lymphatic, respiratory, and cutaneous systems.

In the absence of clinical symptoms, complementary diagnostic techniques, such as histopathological, microbiological, and molecular examination, are fundamental to confirm cases and foci (MOTA, 2006; SILVA et al., 2009; CASTRO, 2015). Studies referring to the monitoring of natural glanders outbreaks help fill gaps in the clinical aspects of the disease including pathogenesis and diagnosis.

In bacterial isolation studies, the macroscopic appearance of colonies was tiny, flat, mucoidal, shiny, transparent, and non-hemolytic (Plaque 01-F). Microscopy revealed non-mobile gram-negative bacilli, suggestive of B. mallei according to Silva et al. (2009) and Gonzalez-Medina et al. (2015). Bacterial isolation is essential for further phenotyping and for molecular epidemiology and strain-resistance studies. In addition to confirming the presence of infection in animals, this technique also supports disease monitoring.

Our study identified the same strain of $B$. mallei observed by Falcão et al. (2019) in northeastern Brazil. This epidemiological finding indicates that disease distribution is related to the trade of animals between states and to animal participation in fairs and agricultural events (FONSECA-RODRÍGUEZ et al., 2019). The same strain was also reported in Turkey (DALIGAULT et al., 2016), a possible warning of the global spread of glanders. 


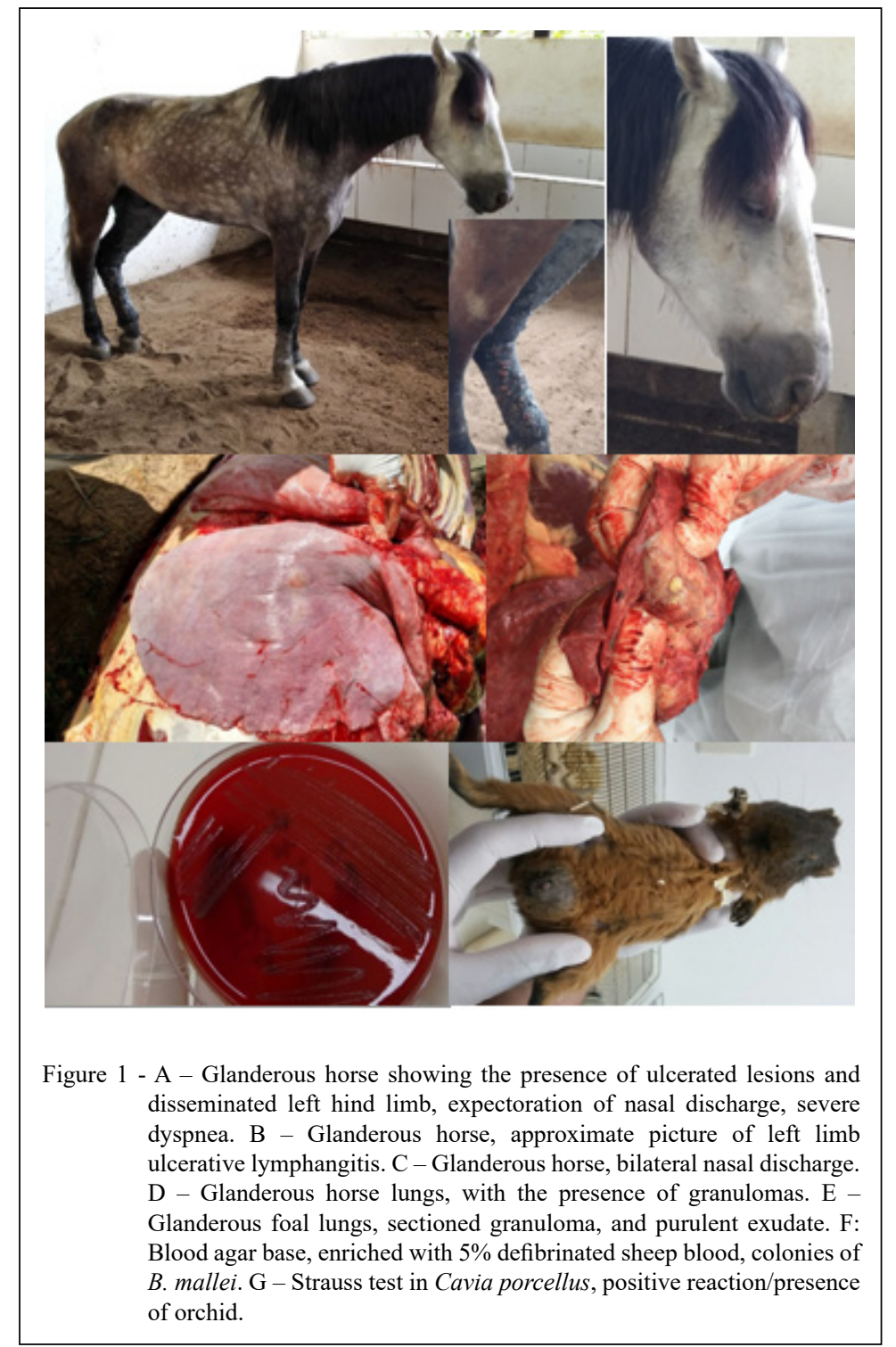

A PCR test to confirm bacterial species is important because of the similarity between $B$. mallei and B. pseudomallei. B. pseudomallei is the causative agent of melioidosis, a disease that affects humans and, occasionally, domestic mammals (DANCE, 2000). Both species share some phenotypic characteristics of resistance (GILLIGAN et al., 2003) and zoonotic capacity, putting them at imminent risk to animal and human health (ROTZ, 2002).

The samples that were obtained tested positive for $B$. mallei (UFAL1 and UFAL2), as indicated by the Strauss test. The clinical signs observed in guinea pigs were testicular edema, testicular hyperemia, dyspnea, testicular mass decrease, and testicular firmness (Plancha 01G). Necropsy revealed bilateral purulent orchitis, hemorrhagic enteritis, splenomegaly, hemorrhagic spermatic cord, and congested lungs. Bacteria were isolated from the necropsy material of all guinea pigs. According to MOTA et al. (2008), infected guinea pigs show increased testicular volume and signs of septicemia $24-48 \mathrm{~h}$ after inoculation, or abscess at the point of inoculation in approximately $3-5 \mathrm{~d}$.

\section{CONCLUSION}

Results indicated that animals infected with glanders may exhibit different clinical patterns, and

Ciência Rural, v.51, n.12, 2021. 
some may even be without signs owing to the chronic character of the disease. Therefore, early diagnosis using sensitive and specific I-ELISA is recommended to reduce the possibility of false-positive results. Anatomopathological, microbiological, and molecular examinations should be performed to confirm disease outbreak in animals without clinical sigs that test positive in the immunoassay.

\section{BIOETHICS AND COMMITTEE APPROVAL}

\section{BIOSECURITY}

The Ethics Committee for the Use of Animals of the Universidade Federal de Alagoas approved this study under license No. 92/2016, under the responsibility of the researcher Profa. Dr. Karla Patrícia Chaves da Silva.

\section{DECLARATION OF CONFLICT OF INTEREST}

The authors have no conflicts of interest to declare. "Monitoring the outbreak of equine glanders in Alagoas, Brazil: Clinical, immunological, molecular, and anatomopathological findings" represents original work. Part of this manuscript, or any other work with substantially similar content of my authorship, was published or considered for publication in another paper, whether in print or electronic format. If requested, we agree to provide data on which the article is based for review by the editors. We guarantee the publication has the approval of all authors, and that they have participated sufficiently to be responsible for the content.

\section{AUTHORS' CONTRIBUTIONS}

All authors contributed equally to the conception and writing of the manuscript. All authors critically revised the manuscript and approved the final version.

\section{REFERENCES}

AL-ANI, F. K., et al. Glanders in equines: Clinical, biochemical and serological studies in Iraq (1998). Veterinarski Arhiv., 68 155-162.

CASTRO, R. S. (2015) Métodos de diagnóstico e estratégias de controle do mormo no brasil. Ciênc. Vet. Tróp., 18, 98-103.

CFMV - Guia Brasileiro de Boas Práticas em Eutanásia em Animais - Conceitos e Procedimentos Recomendados (2013) Brasília. Available from: <http://www.agricultura.gov.br/assuntos/ producao-animal/arquivos-publicacoes-bem-estar-animal/guiabrasileiro-de-boas-praticas-para-a-eutanasia-em-animais.pdf/view. Accessed: Jun. 24, 2019.

DALIGAULT, H. E., et al. (2016) Draft genomes for eight Burkholderia mallei isolates from Turkey. Genome Announc., 4. Available from: $<$ https://mra.asm.org/content/4/1/e01234-15>. Accessed: Jun. 24, 2019. doi: 10.1128/genomeA.01234-15.

DANCE, D. A. (2000) Melioidosis as an emerging global problem. Acta Trop., 74, 115-119. Available from
$<$ https://www.sciencedirect.com/science/article/abs/pii/ S0001706X99000595>. Accessed: Jun. 24, 2019. doi: 10.1016/ s0001-706x(99)00059-5.

FALCÃO, M. V. D., et al. (2019) First record of Burkholderia mallei Turkey 10 strain originating from glanderous equines from Brazil. Brazilian J. Microbiol., 50, 1125-1127. Available from: $<$ http://www.ncbi.nlm.nih.gov/pubmed/31321739>. Accessed: Feb. 12, 2020. doi: 10.1007/s42770-019-00113-2.

FONSECA-RODRÍGUES, O., et al. (2019) Spatiotemporal analysis of Glanders in Brazil. J. Equine Vet. Science. 78, 14-19. Available from: <https://pubmed.ncbi.nlm.nih. gov/31203979/>. Accessed: Feb. 12, 2020. doi: 10.1016/j. jevs.2019.03.216.

GILligAN, P. H., et al. (2003) Burkholderia Stenotrophomoras, Ralstonia, Brevundimonas, Comamonas, and Acidovorax. In: Manual of Clin. Microbiol., Ed: P.R. Murray. p.729-748.

GONZALEZ-MEDINA, S., TOTH, B. and MAWHINNEY, I. (2015) Surveillance focus: Glanders. Vet. Rec., 177, 68-69. Available from: <http://www.ncbi.nlm.nih.gov/ pubmed/26183359>. Accessed: Feb. 12, 2020. doi: 10.1136/ vr.h3772.

KHAN, I., et al. (2013) Glanders in animals: A review on epidemiology, clinical presentation, diagnosis and countermeasures. Transbound. Emerg. Dis., 60, 204 221. Available from: <http://www.ncbi.nlm.nih.gov/ pubmed/22630609>. Accessed: Feb. 12, 2020. doi: 10.1111/j.18651682.2012.01342.x

LEOPOLDINO, D. C. C., OLIVEIRA, R. G. de and ZAPPA, V (2009) Mormo em equinos. Rev. Científica Eletrônica Med. Veterinária, VII, 1-6.

MAPA. Ministério da Agricultura, Pecuária e Abastecimento (2018). Available from: <http://www.agricultura.gov.br/>. Accessed: Feb. 12, 2020.

MOTA, R. A. (2006) Aspectos etiopatológicos, epidemiológicos e clínicos do mormo. Veterinária eZootec., 13,117-124. Available from: $<$ https://rvz.emnuvens.com.br/rvz/article/view/260>. Accessed: Feb. 12, 2020. doi: 10.35172/rvz.2006.v13.260.

MOTA, R. A., et al. (2000) Mormo em eqüídeos nos Estados de Pernambuco e Alagoas. Pesqui. Vet. Bras., 20, 155-159. Available from: <https://www.scielo.br/scielo. php? script $=$ sci_arttext\&pid $=$ S0100-736X2000000400005\&ln $\mathrm{g}=\mathrm{pt} \& \mathrm{t} \operatorname{lng}=\mathrm{pt}>$. Accessed: Feb. 12, 2020.doi: 10.1590/S0100$736 \times 2000000400005$.

MOTA, R. A., et al. (2008) Alterações clínicas em cobaias (Cavia porcellus) inoculados experimentalmente com isolados de campo de Burkholderia mallei de eqüídeos com mormo. Med. Veterinária, 2, 1-9. Available from: <http:// www.journals.ufrpe.br/index.php/medicinaveterinaria/article/ view/700>. Accessed: Feb. 12, 2020. doi: 10.1590/S0100 736 X2014000100010.

MOTA, R. A; RIBEIRO, M. G. MORMO. In: Megid, J.; Ribeiro, M. G.; Paes, A. C. (Eds). (2016) Doenças infecciosas em animais de produção e de companhia. 1. Ed. Roca, Rio de Janeiro. 
RADOSTITS, O. M., et al. (2010) Clínica veterinária: um tratado de doenças dos bovinos, ovinos, caprinos e equinos, Guanabara Koogan, São Paulo.

ROTZ, L. D., et al. (2002). Public health assessment of the potential of biological terrorism agents. Emerg. Infec. Dis., 8, 225 230. Available from: $<$ https://pubmed.ncbi.nlm.nih.gov/11897082/>. Accessed: Feb. 12, 2020. doi: 10.3201/eid0802.010164.
SAID, N. C., NARDI JÚNIOR, G., DOMINGUES, P. F. (2016) Mormo em equinos e a biosegurança no agronegócio. Tekhne e Logos. 7, 1-2.

SILVA, K. P. C., et al. (2009) Phenotypic and molecular characterization of Burkholderia mallei isolated in northeastern Brazil. Pesqui. Vet. Bras., 29, 439-444. Available from: <https:// www.scielo.br/pdf/pvb/v29n5/15.pdf >. Accessed: Feb. 12, 2020. 